\title{
Ocean acidification and nutrient limitation synergistically reduce growth and photosynthetic performances of a green tide alga Ulva linza
}

\author{
Guang Gao ${ }^{1,2,3}$, John Beardall ${ }^{4}$, Menglin Bao ${ }^{1}$, Can Wang ${ }^{1}$, Wangwang Ren ${ }^{2}$, and Juntian Xu ${ }^{1,2}$ \\ ${ }^{1}$ Jiangsu Key Laboratory of Marine Bioresources and Environment, Huaihai Institute of Technology, \\ Lianyungang, 222005, China \\ ${ }^{2}$ Co-Innovation Center of Jiangsu Marine Bio-industry Technology, Lianyungang 222005, China \\ ${ }^{3}$ State Key Laboratory of Marine Environmental Science, Xiamen University, Xiamen 361005, China \\ ${ }^{4}$ School of Biological Sciences, Monash University, Clayton, Victoria 3800, Australia
}

Correspondence: Juntian Xu (jtxu@hhit.edu.cn)

Received: 3 January 2018 - Discussion started: 13 February 2018

Revised: 24 April 2018 - Accepted: 22 May 2018 - Published: 11 June 2018

\begin{abstract}
Large-scale green tides have been invading the coastal zones of the western Yellow Sea annually since 2008. Meanwhile, oceans are becoming more acidic due to continuous absorption of anthropogenic carbon dioxide, and intensive seaweed cultivation in Chinese coastal areas is leading to severe regional nutrient limitation. However, little is known about the combined effects of global and local stressors on the eco-physiology of bloom-forming algae. We cultured Ulva linza for 9-16 days under two levels of $p \mathrm{CO}_{2}$ (400 and $1000 \mu \mathrm{atm}$ ) and four treatments of nutrients (nutrient repletion, $\mathrm{N}$ limitation, $\mathrm{P}$ limitation, and $\mathrm{N}-\mathrm{P}$ limitation) to investigate the physiological responses of this green tide alga to the combination of ocean acidification and nutrient limitation. For both sporelings and adult plants, elevated $p \mathrm{CO}_{2}$ did not affect the growth rate when cultured under nutrient-replete conditions but reduced it under $\mathrm{P}$ limitation; $\mathrm{N}$ or $\mathrm{P}$ limitations by themselves reduced growth rate. $\mathrm{P}$ limitation resulted in a larger inhibition in growth for sporelings compared to adult plants. Sporelings under P limitation did not reach the mature stage after 16 days of culture while those under P repletion became mature by day 11 . Elevated $p \mathrm{CO}_{2}$ reduced net photosynthetic rate for all nutrient treatments but increased nitrate reductase activity and soluble protein content under P-replete conditions. N or P limitation reduced nitrate reductase activity and soluble protein content. These findings indicate that ocean acidification and nutrient limitation would synergistically reduce the growth
\end{abstract}

of Ulva species and may thus hinder the occurrence of green tides in a future ocean environment.

\section{Introduction}

Seaweeds are a group of organisms that play a vital role in the function of coastal ecosystems. They provide diverse habitats and breeding areas for a large number of organisms including crustaceans, other invertebrates and fish. In addition, in spite of only occupying a small part of the world's oceans, seaweeds account for approximately $10 \%$ of the total oceanic primary productivity due to their high densities (Wiencke and Bischof, 2012). Consequently, they are of importance in the global carbon cycle and in modulating climate change. In addition to high ecological significance, seaweeds are also economically important. They have been widely used in the industry for food, chemical products, pharmaceuticals, cosmetics, etc. (Wang et al., 2017). The increasing demand has resulted in the fast development of seaweed cultivation and successful cultivation has been carried out worldwide, particularly in Asian countries. Among the diverse range of seaweeds, Ulva, a cosmopolitan genus in green seaweeds, is common from tropical to polar areas, from freshwater to fully saline environments, due to its robustness in acclimating to a variety of salinity and water temperature conditions (Gao et al., 2017b). Thanks to their strong capacity for nutrient uptake and quick growth, Ulva is the only genus that causes 
green tides due to massive growth (Smetacek and Zingone, 2013; Gao et al., 2017d). Green tides have received increasing concerns globally due to their ecological and economic impacts. Firstly, they can hinder shore-based activities by preventing small boats, swimmers and tourists from accessing the sea due to their sheer physical mass. Furthermore, nutrients could be re-released to the seawaters and toxic hydrogen sulfide $\left(\mathrm{H}_{2} \mathrm{~S}\right)$ could be produced when thalli decompose, leading to highly eutrophic, anoxic conditions and the spread of coastal dead zones (Smetacek and Zingone, 2013).

Atmospheric carbon dioxide $\left(\mathrm{CO}_{2}\right)$ has continuously increased from 278 to 407 parts per million since the industrial revolution (NOAA, 2017). The global ocean has absorbed around $30 \%$ of anthropogenic $\mathrm{CO}_{2}$ emissions since 1750 , leading to the decrease in seawater $\mathrm{pH}$ termed ocean acidification (Gattuso et al., 2015). Ocean acidification is not only changing the fundamental chemistry and physics in the oceans but also imposing significant impacts on marine organisms (Mostofa et al., 2016). In terms of marine algae, extensive studies have been conducted on phytoplankton species (McCarthy et al., 2012; Li et al., 2015; Gao et al., 2018; Yuan et al., 2018) or communities (Gao et al., 2012, 2017c; Eberlein et al., 2017). Depending on experimental conditions or species, the effects of ocean acidification on the growth and photosynthesis of phytoplankton could be positive (McCarthy et al., 2012), neutral (Boelen et al., 2011) or negative (Gao et al., 2012). Compared to phytoplankton, studies regarding seaweeds are relatively few. Recently, however, there have been increasing concerns about the responses of seaweeds, particularly Ulva species, to ocean acidification (Xu and Gao, 2012; Rautenberger et al., 2015; Gao et al., 2016, 2017a). By analysing the literature, it is found that life stage can affect the effects of ocean acidification on growth of Ulva species. Ocean acidification generally increases growth of Ulva species at early life stages (Xu and Gao, 2012; Gao et al., 2016) but does not affect or even reduces growth of Ulva species at late life stages (Gao et al., 2017a). A possible explanation for the differential effects of ocean acidification is that higher $\mathrm{CO}_{2}$ could induce more reproduction events for adult (Gao et al., 2017a).

Nutrients are crucial for growth and development of seaweeds. Nitrogen and phosphorus, two key nutrient components for seaweeds, are commonly thought to be limiting in natural seawater (Elser et al., 2007; Müller and Mitrovic, 2015). Accordingly, enrichment of nitrogen and phosphorus generally stimulate growth of seaweeds (Msuya and Neori, 2008; Luo et al., 2012; Xu et al., 2017). There are studies indicating that $\mathrm{N}$ availability controls the biomass of seaweeds in temperate coastal areas (Nixon and Pilson, 1983; Howarth et al., 2000) and $\mathrm{P}$ limitation is the dominating factor for macroalgal growth in tropical latitudes (Lapointe, 1997; Lapointe et al., 2010). However, phosphorus appears to play a more important role in limiting the growth of Ulva sp. compared to nitrogen in a temperate coastal area (Villares et al., 1999). In addition, Teichberg et al. (2010) investigated the effects of nitrogen and phosphorus enrichment on growth of $U$. spp. at nine sites across temperate and tropical areas. It was found that Ulva's growth was controlled by dissolved inorganic nitrogen (DIN) when ambient DIN levels were low and by phosphorus when DIN levels were higher, irrespective of geographic or latitudinal differences (Teichberg et al., 2010).

In addition to independent effects, the combined effects of ocean acidification and nutrients on seaweeds have also been studied. Baydend et al. (2010) documented that both ocean acidification and elevated nutrient concentration reduced the growth of coralline crusts and the combination of the factors led to a further decrease in growth. However, Xu et al. (2017) reported that ocean acidification and $\mathrm{P}$ enrichment did not enhance the growth of the brown seaweed Sargassum muticum when further applied together, although either alone had a positive effect. The studies above indicate that the combined effects of ocean acidification and eutrophication might be species-specific.

Until now, most studies regarding the effect of ocean acidification on seaweeds have been based on nutrient-replete conditions. In the field, the nutrient levels could be limiting and this is particularly true in the areas of intensive seaweed cultivation. For instance, the nitrogen and phosphorus concentrations in Porphyra cultivation areas could be half of those in non-cultivation areas (He et al., 2008; Wu et al., 2015). Little is known about how seaweeds grown under nutrient-limited conditions respond to ocean acidification. In addition, the young and adult thalli may have differential responses to ocean acidification and nutrient limitation (Gao et al., 2017a). Therefore, here we investigated the effects of ocean acidification and nutrient limitation on the ecologically and commercially important seaweed $U$. linz $a$ at different life stages to understand how Ulva species respond to the combination of global climate change and local stressors.

\section{Materials and methods}

\subsection{Sample preparation and culture conditions}

To investigate whether life stage affects algal response to ocean acidification and nutrients, both spores and adults of $U$. linza were used in this study. Fertile and vegetative thalli $(\sim 5 \mathrm{~cm})$ were collected from the coastal water of Lianyungang $\left(119.3^{\circ} \mathrm{E}, 34.5^{\circ} \mathrm{N}\right)$, Jiangsu province, China. The fronds were put into in a cooling box $\left(4-6^{\circ} \mathrm{C}\right)$ and taken to the laboratory within $1 \mathrm{~h}$. They were then rinsed with filtered $(0.2 \mu \mathrm{m})$ natural seawater to remove any sediment and small grazers. Spores, released from the fertile thalli after being exposed to high light $\left(600 \mu \mathrm{mol}\right.$ photons $\left.\mathrm{m}^{-2} \mathrm{~s}^{-1}\right)$ for $12 \mathrm{~h}$, were allowed to settle and attach to glass slides in darkness for $12 \mathrm{~h}$. 
The settled spores were cultured in $1 \mathrm{~L}$ balloon flasks containing $900 \mathrm{~mL}$ of media under four nutrient regimes (higher nitrate and higher phosphate (HNHP), lower nitrate and higher phosphate (LNHP), higher nitrate and lower phosphate (HNLP), lower nitrate and lower phosphate (LNLP)) and two $p \mathrm{CO}_{2}$ (400 (LC) and 1000 (HC) $\mu$ atm) to explore the interactive effects of ocean acidification and nutrient limitation. The treatment of lower $p \mathrm{CO}_{2}$, higher nitrate and higher phosphate (LCHNHP) was set as the control. Twenty volumes of natural seawater $\left(30.7 \mu \mathrm{mol} \mathrm{L} \mathrm{L}^{-1} \mathrm{~N}\right.$ and $1.0 \mu \mathrm{mol} \mathrm{L}^{-1} \mathrm{P}$ ) were diluted with 80 volumes of artificial seawater without $\mathrm{N}$ or $\mathrm{P}$ to make a LNLP medium $\left(6.1 \mu \mathrm{mol} \mathrm{L}{ }^{-1} \mathrm{~N}\right.$ and $\left.0.2 \mu \mathrm{mol} \mathrm{L}{ }^{-1} \mathrm{P}\right)$. The medium for $\mathrm{P}$ limitation (HNLP, $106.1 \mu \mathrm{mol} \mathrm{L}^{-1} \mathrm{~N}$ and $0.2 \mu \mathrm{mol} \mathrm{L}^{-1} \mathrm{P}$ ) was made of LNLP medium plus $100 \mu \mathrm{mol} N$. The medium for $\mathrm{N}$ limitation (LNHP, $6.1 \mu \mathrm{mol} \mathrm{L}^{-1} \mathrm{~N}$ and $10.2 \mu \mathrm{mol} \mathrm{L}^{-1} \mathrm{P}$ ) was made of LNLP medium plus $10 \mu \mathrm{mol} P$. The $\mathrm{N}$ - and P-replete medium (HNHP, $106.1 \mu \mathrm{mol} \mathrm{L}{ }^{-1} \mathrm{~N}$ and $10.2 \mu \mathrm{mol} \mathrm{L}^{-1} \mathrm{P}$ ) was made of LNLP medium plus $100 \mu \mathrm{mol} \mathrm{L}^{-1} \mathrm{~N}$ and $10 \mu \mathrm{mol} \mathrm{L}{ }^{-1} \mathrm{P}$. The $400 \mu \mathrm{atm} p \mathrm{CO}_{2}$ level was maintained by bubbling ambient air, and the $1000 \mu$ atm $p \mathrm{CO}_{2}$ level was achieved using a $\mathrm{CO}_{2}$ plant chamber (HP1000 GD, Wuhan Ruihua Instrument \& Equipment Ltd, China) with the variation of $\mathrm{CO}_{2}$ less than $5 \%$ of the set values. The incubation light intensity was $300 \mu \mathrm{mol}$ photons $\mathrm{m}^{-2} \mathrm{~s}^{-1}$ (daylight fluorescent tubes, 21W, Philips), with a 12:12 (light: dark) light period, and the incubation temperature was $20^{\circ} \mathrm{C}$. The samples were collected in March 2017 and the light density of $300 \mu \mathrm{mol}$ photons $\mathrm{m}^{-2} \mathrm{~s}^{-1}$ used for the cultures was close to the ambient light level at the sample collecting site. Light density was measured by a Quantum Scalar Laboratory (QSL) radiometer (QSL-2100, Biospherical Instruments, Inc., USA) that detects photosynthetically active radiation (400-700 $\mathrm{nm}$ ). Once the sporelings had attained a length of $1 \mathrm{~cm}$ they were detached from the glass slides and dispersed directly into the treatment flasks. The cultures were bubbled with ambient or $\mathrm{CO}_{2}$-enriched air at a rate of $300 \mathrm{~mL} \mathrm{~min}^{-1}$ to make the thalli roll up and down.

The culture conditions for adult Ulva were the same as for the spores. The culture density was less than $0.1 \mathrm{~g} \mathrm{~L}^{-1}$ and the $\mathrm{pH}$ fluctuation was less than 0.03 units. Low culture density and aeration with ambient and $\mathrm{CO}_{2}$-enriched air contributed to the stable $\mathrm{pH}$ in the cultures. The cultures were carried out in triplicates and lasted 16 days for spores and 9 days for adult thalli. The media were renewed every 2 days. The cultures had been finished before the thalli became reproductive as the aim of this study focused on the growth and photosynthesis. Different cultivation periods were used because the periods were different for sporeling and adult to become reproductive. These cultivation periods are enough for U. linza's acclimation to ocean acidification (Eggert, 2012; Gao et al., 2016). The following parameters were measured at the end of the culture periods for each flask under each treatment.

\subsection{Measurement of growth}

The variations in sporeling length and adult fresh mass (FM) were recorded every 2 days. The length of sporelings was measured by a microscope (Leica DM500, Germany) with a micro-ruler. The fresh mass of adults was determined by weighing using a balance (BS $124 \mathrm{~S}$, Sartorius, Germany) after removing surface water by gently blotting the thalli with tissue paper. The specific growth rate (SGR) was estimated as follows: $\operatorname{SGR}(\%)=\left(\ln M_{t 2}-\ln M_{t 1}\right) / t \times 100$, where $M_{t 1}$ is the initial length for sporelings or initial fresh mass for adults; $M_{t 2}$ is the length or fresh mass after $t$ days (16 days for sporeling and 9 days for adult) culture. Due to the tiny mass of sporelings, length rather than mass was used to determine SGR for sporelings and only adult thalli were used for measurements of the following aspects of physiological performance.

\subsection{Chlorophyll fluorescence assessment}

The relative electron transport rate (rETR) was measured using a pulse amplitude modulation (PAM) fluorometer (PAM-2100, Walz, Germany). The measuring light was $0.01 \mu \mathrm{mol}$ photons $\mathrm{m}^{-2} \mathrm{~s}^{-1}$ and actinic light was set as the same as the growth light $\left(300 \mu \mathrm{mol}\right.$ photons $\left.\mathrm{m}^{-2} \mathrm{~s}^{-1}\right)$. The saturating pulse was set to $5000 \mu \mathrm{mol}$ photons $\mathrm{m}^{-2} \mathrm{~s}^{-1}$ $(0.8 \mathrm{~s})$. The $\mathrm{rETR}\left(\mu \mathrm{mol} \mathrm{e}^{-} \mathrm{m}^{-2} \mathrm{~s}^{-1}\right)=\left(F_{\mathrm{m}}^{\prime}-F_{t}\right) / F_{\mathrm{m}}^{\prime} \times 0.5 \times$ PFD, where $F_{\mathrm{m}}^{\prime}$ is the maximal fluorescence levels from algae in the light. $F_{t}$ is the fluorescence at an excitation level. PFD is the actinic light density.

\subsection{Determination of photosynthesis}

The net photosynthetic rate of thalli was measured by a Clark-type oxygen electrode (YSI model 5300A). Algal individuals were cut into $1 \mathrm{~cm}$ long segments with a scissors. Approximately $0.02 \mathrm{~g}$ segments were randomly selected and transferred to the oxygen electrode cuvette with $8 \mathrm{~mL}$ of media from the culture flask, being stirred. The conditions for temperature and light were set the same as those for growth. The net photosynthetic rate was determined by the increase in the oxygen content in the media over $5 \mathrm{~min}$. The unit for net photosynthetic rate (NPR) was $\mu \mathrm{mol} \mathrm{O}_{2} \mathrm{~g}^{-1} \mathrm{FM} \mathrm{h}^{-1}$.

\subsection{Measurement of photosynthetic pigments}

Approximately $20 \mathrm{mg}$ of fresh mass thalli was extracted in $5 \mathrm{~mL}$ methanol at $4{ }^{\circ} \mathrm{C}$ for $24 \mathrm{~h}$ in darkness. Then the absorbance values of samples at $665\left(A_{665}\right)$ and $652\left(A_{652}\right) \mathrm{nm}$ were read with a UV-visible spectrophotometer (Ultrospect 3300 pro, Amersham Bioscience, Sweden). The content of Chl $a$ and Chl $b$ was determined as follows: 
Table 1. Parameters of the seawater carbonate system in different cultures. LC, $400 \mu a t m ; H C, 1000 \mu a t m ; \mathrm{LN}^{2} 6.1 \mu \mathrm{mol} \mathrm{L}^{-1} ; \mathrm{LP}$, $0.2 \mu \mathrm{mol} \mathrm{L}-1 ; \mathrm{HN}, 106.1 \mu \mathrm{mol} \mathrm{L}-1 ; \mathrm{HP}, 10.2 \mu \mathrm{mol} \mathrm{L}-1$. DIC = dissolved inorganic carbon, TA = total alkalinity. Data are the means \pm SD $(n=3)$.

\begin{tabular}{|c|c|c|c|c|c|c|c|}
\hline Treatment & $\begin{array}{l}p \mathrm{CO}_{2} \\
(\mu \mathrm{atm})\end{array}$ & $\mathrm{pH}$ & $\begin{array}{c}\text { DIC } \\
\left(\mu \mathrm{mol} \mathrm{kg}^{-1}\right)\end{array}$ & $\begin{array}{c}\mathrm{CO}_{2} \\
\left(\mu \mathrm{mol} \mathrm{kg}^{-1}\right)\end{array}$ & $\begin{array}{c}\mathrm{HCO}_{3}^{-} \\
\left(\mu \mathrm{mol} \mathrm{kg}^{-1}\right)\end{array}$ & $\begin{array}{c}\mathrm{CO}_{3}^{2-} \\
\left(\mu \mathrm{mol} \mathrm{kg}^{-1}\right)\end{array}$ & $\begin{array}{c}\mathrm{TA} \\
\left(\mu \mathrm{mol} \mathrm{kg}^{-1}\right)\end{array}$ \\
\hline LCHNHP & $373.8 \pm 6.3$ & $8.21 \pm 0.01$ & $1991.9 \pm 49.4$ & $12.3 \pm 0.2$ & $1805.3 \pm 43.3$ & $174.2 \pm 6.1$ & $2243.7 \pm 55.8$ \\
\hline LCLNHP & $381.3 \pm 2.9$ & $8.20 \pm 0.01$ & $2015.1 \pm 50.4$ & $12.6 \pm 0.1$ & $1827.4 \pm 42.0$ & $175.1 \pm 8.5$ & $2267.0 \pm 60.5$ \\
\hline LCHNLP & $400.4 \pm 9.0$ & $8.19 \pm 0.01$ & $2029.9 \pm 50.1$ & $13.2 \pm 0.3$ & $1846.4 \pm 43.1$ & $170.2 \pm 7.7$ & $2262.7 \pm 58.2$ \\
\hline LCLNLP & $397.4 \pm 8.4$ & $8.18 \pm 0.01$ & $1998.2 \pm 39.0$ & $13.1 \pm 0.3$ & $1818.7 \pm 35.1$ & $166.3 \pm 4.3$ & $2226.7 \pm 42.9$ \\
\hline HCHNHP & $929.1 \pm 24.8$ & $7.86 \pm 0.01$ & $2154.6 \pm 52.5$ & $30.7 \pm 0.8$ & $2034.9 \pm 49.5$ & $89.1 \pm 2.6$ & $2263.3 \pm 54.2$ \\
\hline HCLNHP & $958.8 \pm 5.2$ & $7.85 \pm 0.01$ & $2155.0 \pm 42.0$ & $31.6 \pm 0.2$ & $2036.8 \pm 38.5$ & $86.5 \pm 3.6$ & $2259.0 \pm 46.5$ \\
\hline HCHNLP & $976.1 \pm 10.9$ & $7.84 \pm 0.01$ & $2159.3 \pm 38.7$ & $32.2 \pm 0.4$ & $2041.7 \pm 36.1$ & $85.4 \pm 2.5$ & $2250.7 \pm 41.3$ \\
\hline HCLNLP & $1020.2 \pm 51.8$ & $7.82 \pm 0.03$ & $2117.9 \pm 31.0$ & $33.7 \pm 1.7$ & $2005.3 \pm 28.0$ & $78.9 \pm 5.2$ & $2199.3 \pm 37.4$ \\
\hline
\end{tabular}

$$
\begin{aligned}
\text { Chl } a\left(\mathrm{mgg} \mathrm{FM}^{-1}\right) & =\left(16.29 \times A_{665}-8.54 \times A_{652}\right) \\
& \times V /(M \times 1000), \\
\text { Chl } b\left(\mathrm{mgg} \mathrm{FM}^{-1}\right) & =\left(30.66 \times A_{652}-13.58 \times A_{665}\right) \\
& \times V /(M \times 1000),
\end{aligned}
$$

where $V$ is the volume of methanol used and $M$ is the mass of thalli used.

\subsection{Assessment of nitrate reductase activity}

Nitrate reductase activity (NRA) of thalli was estimated based on a modified method of Corzo and Niell (1991). The measurement was conducted during the local noon period (13:00 LT) since the activity of nitrate reductase usually displays circadian periodicity with a maximum during the light period and a minimum in darkness (Velasco et al., 1989; Deng et al., 1991). Approximately $0.3 \mathrm{~g}$ (FM) of thalli from each culture condition was incubated for $1 \mathrm{~h}$ at $20^{\circ} \mathrm{C}$ in darkness in the reaction solution $(10 \mathrm{~mL})$, which contained $0.1 \mathrm{M}$ phosphate buffer, $0.1 \%$ propanol $(v / v), 50 \mathrm{mM}$ $\mathrm{KNO}_{3}, 0.01 \mathrm{mM}$ glucose and $0.5 \mathrm{mM}$ EDTA, with a $\mathrm{pH}$ of 8.0. The mixture was flushed with pure $\mathrm{N}_{2}$ gas $(99.999 \%$ ) for 2 min to obtain an anaerobic state before the incubation. The concentration of nitrite produced was determined colorimetrically at $540 \mathrm{~nm}$ (Xu et al., 2017). The NRA was expressed as $\mu \mathrm{mol} \mathrm{NO}-\mathrm{g}^{-1} \mathrm{FMh}^{-1}$.

\subsection{Estimation of soluble protein}

Approximately $0.2 \mathrm{~g}$ of FM thalli under each treatment at the end of the culture period were ground in a mortar with extraction solution $\left(0.1 \mathrm{~mol} \mathrm{~L}^{-1}\right.$ phosphate buffer, $\left.\mathrm{pH} 6.8\right)$ and then centrifuged for $10 \mathrm{~min}$ at $5000 \mathrm{~g}$. Content of soluble protein was estimated from the supernatant using the Bradford (1976) assay, with bovine serum albumin as a standard.

\subsection{Statistical analysis}

The results in this study were expressed as means of replicates \pm standard deviation and the data were analysed using the software SPSS v.22. The data under every treatment conformed to a normal distribution (Shapiro-Wilk, $P>0.05$ ) and the variances could be considered equal (Levene's test, $P>0.05$ ). Two-way multivariate analysis of variance (MANOVA) was conducted to assess the effects of $p \mathrm{CO}_{2}$ and nutrients on seawater carbonate parameters. Repeated measure analysis of variance (RM-ANOVA) was conducted to analyse the effects of culture time on the length of young and adult thalli, with Bonferroni for post hoc investigation. Two-way analysis of variance (ANOVA) was conducted to assess the effects of $p \mathrm{CO}_{2}$ and nutrients on specific growth rate, net photosynthesis rate, $\mathrm{rETR}, \mathrm{Chl} a, \mathrm{Chl} b$, soluble protein and NRA. Tukey's honest significant difference (Tukey HSD) was conducted for MANOVA and ANOVA post hoc investigation. Paired $t$ tests were used to compare the differences in specific growth rate between young and adult thalli under each treatment. A confidence interval of $95 \%$ was set for all tests.

\section{Results}

The carbonate system under each treatment was recorded (Table 1). Both $p \mathrm{CO}_{2}$ and nutrient treatments had a significant effect on carbonate parameters (Table 2). Elevated $p \mathrm{CO}_{2}$ reduced $\mathrm{pH}$ and $\mathrm{CO}_{3}^{-}$and increased DIC, $\mathrm{CO}_{2}$ and $\mathrm{HCO}_{3}^{-}(P<0.001$ for all parameters above $)$ but did not affect TA $(P=0.740)$. P limitation (LP) increased $p \mathrm{CO}_{2}(P=$ $0.002)$ and $\mathrm{CO}_{2}(P=0.002)$ and reduced $\mathrm{pH}(P=0.001)$ and $\mathrm{CO}_{3}^{2-}(P=0.046)$.

The length for both young and adult $U$. linza varied with culture time, and the patterns under different $p \mathrm{CO}_{2}$ and/or nutrient conditions were inconsistent (Fig. 1 and Table 3). For example, the length gap between HP and LP increased with culture time (Bonferroni, $P<0.01$ ). It is worth noting 
Table 2. Two-way multivariate analysis of variance for the effects of $p \mathrm{CO}_{2}$ and nutrients on $\mathrm{pH}$, dissolved inorganic carbon (DIC), $\mathrm{HCO}_{3}^{-}$, $\mathrm{CO}_{3}^{2-}, \mathrm{CO}_{2}$ and total alkalinity (TA) in the seawater. The $p \mathrm{CO}_{2}{ }^{*}$ nutrient means the interactive effect of $p \mathrm{CO}_{2}$ and nutrients, df means degree of freedom, $F$ means the value of $F$ statistic, and Sig. means $p$ value.

\begin{tabular}{|c|c|c|c|c|c|c|c|c|c|c|c|c|c|}
\hline \multirow[t]{2}{*}{ Source } & \multirow[b]{2}{*}{ df } & \multicolumn{2}{|c|}{$\mathrm{pH}$} & \multicolumn{2}{|c|}{ DIC } & \multicolumn{2}{|c|}{$\mathrm{HCO}_{3}^{-}$} & \multicolumn{2}{|c|}{$\mathrm{CO}_{3}^{2-}$} & \multicolumn{2}{|c|}{$\mathrm{CO}_{2}$} & \multicolumn{2}{|c|}{$\mathrm{TA}$} \\
\hline & & $F$ & Sig. & $F$ & Sig. & $F$ & Sig. & $F$ & Sig. $\mid$ & $F$ & Sig. & $F$ & Sig. \\
\hline$p \mathrm{CO}_{2}$ & 1 & 5237.765 & $<0.001$ & 57.132 & $<0.001$ & 158.536 & $<0.001$ & 1504.349 & $<0.001$ & 4486.773 & $<0.001$ & 0.114 & 0.740 \\
\hline Nutrient & 3 & 9.765 & 0.001 & 0.747 & 0.540 & 0.741 & 0.543 & 3.336 & 0.046 & 7.999 & 0.002 & 1.225 & 0.333 \\
\hline$p \mathrm{CO}_{2}{ }^{*}$ nutrient & 3 & 1.294 & 0.311 & 0.256 & 0.856 & 0.332 & 0.802 & 0.162 & 0.921 & 2.683 & 0.082 & 0.228 & 0.876 \\
\hline Error & 16 & & & & & & & & & & & & \\
\hline
\end{tabular}
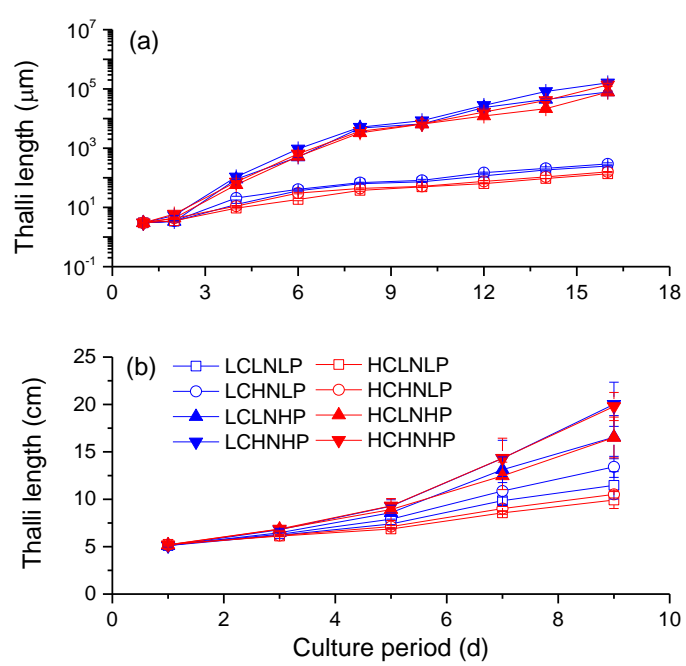

Figure 1. Length changes in young (a) and adult (b) $U$. linza grown under various conditions during the culture periods. LC, $400 \mu \mathrm{atm}$; HC, $1000 \mu \mathrm{atm}$; LN, $6.1 \mu \mathrm{mol} \mathrm{L}^{-1}$; LP, $0.2 \mu \mathrm{mol} \mathrm{L}^{-1}$; $\mathrm{HN}, 106.1 \mu \mathrm{mol} \mathrm{L}-1$; HP, $10.2 \mu \mathrm{mol} \mathrm{L}^{-1}$. The error bars indicate the standard deviations $(n=3)$.

that LP dramatically inhibited the development of sporelings as the length under HP was 78 274-160290 $\mu \mathrm{m}$ while it was only $137-250 \mu \mathrm{m}$ under LP at the end of 16 days of culture.

Based on the initial and final length (young thalli) or mass (adult thalli), specific growth rate was calculated (Fig. 2). Nutrients and $p \mathrm{CO}_{2}$ interacted to affect the growth of both young and adult $U$. linza (Table 4). Specifically, post hoc Tukey HSD comparison $(P=0.05)$ showed that HC reduced growth at LP but did not affect it at HP, suggesting an interactive effect between $P$ and C. Nutrient supply had an effect on growth but the patterns between young and adult thalli were different (Table 4). For young thalli, post hoc Tukey HSD comparison $(P=0.05)$ showed that $\mathrm{N}$ limitation did not reduce growth, $\mathrm{P}$ limitation dramatically reduced the growth, and the combination of $\mathrm{N}$ and $\mathrm{P}$ limitation did not lead to a further decrease regardless of $p \mathrm{CO}_{2}$ conditions. For adult thalli, either $\mathrm{N}(P<0.001)$ or $\mathrm{P}(P<0.001)$ limitation reduced growth and the combination of these nutrient limitations resulted in a further decrease $(P=0.011)$. In addition,

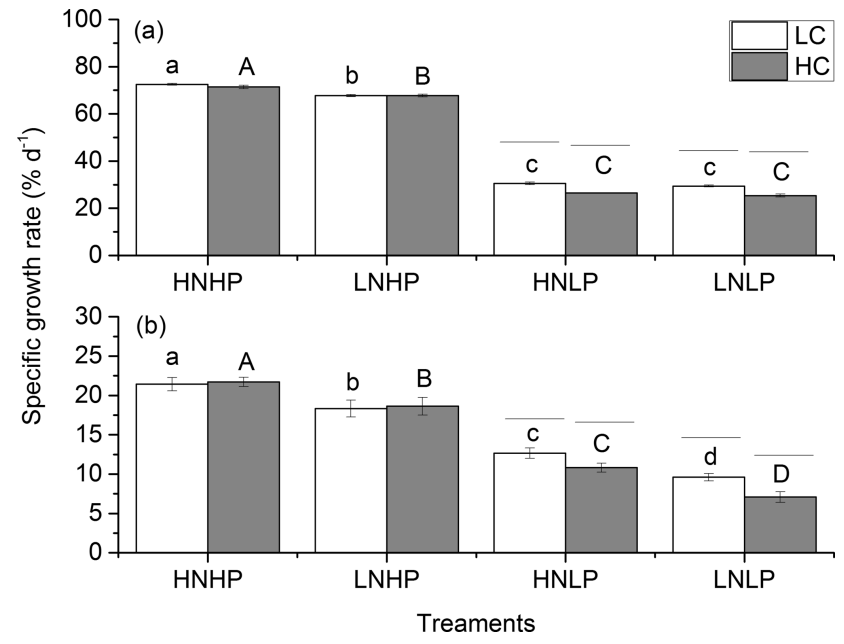

Figure 2. Specific growth rate $\left(\% \mathrm{~d}^{-1}\right)$ of young (a) and adult (b) $U$. linza grown under various conditions. The specific growth rate for young and adult thalli were calculated based on the initial and final length (for young thalli over a 16-day culture) or mass (for adult thalli over a 9-day). LC, $400 \mu \mathrm{atm}$; HC, $1000 \mu \mathrm{atm}$; $\mathrm{LN}, 6.1 \mu \mathrm{mol} \mathrm{L}^{-1}$; LP, $0.2 \mu \mathrm{mol} \mathrm{L}^{-1}$; HN, $106.1 \mu \mathrm{mol} \mathrm{L}^{-1}$; HP, $10.2 \mu \mathrm{mol} \mathrm{L}{ }^{-1}$. The error bars indicate the standard deviations $(n=$ 3 ). Different letters (lower case for LC and capital for HC) above the error bars represent significant differences $(P<0.05)$ among nutrient treatments while horizontal bars represent significant differences $(P<0.05)$ between $\mathrm{LC}$ and $\mathrm{HC}$ within a nutrient treatment.

young thalli had higher growth rates under each condition compared to adult plants $(P<0.001)$.

The effects of $p \mathrm{CO}_{2}$ and nutrients on the net photosynthetic rate of adult thalli were also investigated (Fig. 3a). Both $p \mathrm{CO}_{2}$ and nutrients had a significant effect on net photosynthetic rate (Table 4) and HC reduced NPR under each nutrient condition $(P<0.05)$. In terms of the effect of nutrients, LN $(P=0.006)$ or LP $(P<0.001)$ alone decreased NPR and the combination of LN and LP led to a further decrease under LC $(P<0.001)$. Under $\mathrm{HC}$, post hoc Tukey HSD comparison $(P=0.05)$ showed that both $\mathrm{LN}$ and LP reduced NPR but the combination of LN and LP did not decrease NPR further. In terms of dark respiration rate (Fig. 3b), neither $p \mathrm{CO}_{2}$ nor nutrients had a significant effect on it (Table 4). 
Table 3. Repeated analysis of variance for the effects of culture time on length changes in young and adult $U$. linza grown under various $p \mathrm{CO}_{2}$ and nutrient conditions. Time* $p \mathrm{CO}_{2}$ means the interactive effect of time and $p \mathrm{CO}_{2}$, Time* nutrient means the interactive effect of time and nutrients, and Time* $p \mathrm{CO}_{2}{ }^{*}$ nutrient means the interactive effect of Time, $p \mathrm{CO}_{2}$ and nutrients; df means degree of freedom, $F$ means the value of $F$ statistic, and Sig. means $p$ value.

\begin{tabular}{lrrr|rrr}
\hline Source & \multicolumn{3}{c|}{ Growth of young $U$. linza } & \multicolumn{3}{|c}{ Growth of adult $U$. linza } \\
\cline { 2 - 7 } & df & $F$ & Sig. & df & $F$ & Sig. \\
\hline Time & 8 & 1153.328 & $<0.001$ & 4 & 571.769 & $<0.001$ \\
Time* $p \mathrm{CO}_{2}$ & 8 & 23.582 & $<0.001$ & 4 & 3.158 & 0.020 \\
Time* Nutrient & 24 & 457.170 & $<0.001$ & 12 & 28.505 & $<0.001$ \\
Time* $p \mathrm{CO}_{2}{ }^{*}$ nutrient & 24 & 10.585 & $<0.001$ & 12 & 0.689 & 0.756 \\
Error & 128 & & & 64 & & \\
\hline
\end{tabular}

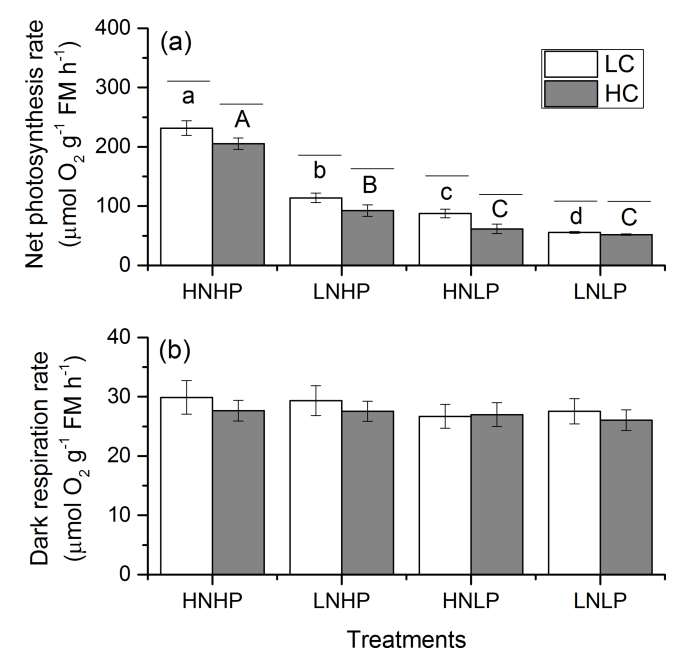

Figure 3. Net photosynthetic (a) and dark respiration (b) rates of adult $U$. linza grown under various conditions. LC, $400 \mu \mathrm{atm}$; HC, $1000 \mu \mathrm{atm}$; LN, $6.1 \mu \mathrm{mol} \mathrm{L}^{-1}$; LP, $0.2 \mu \mathrm{mol} \mathrm{L}^{-1}$; $\mathrm{HN}, 106.1 \mu \mathrm{mol} \mathrm{L}{ }^{-1}$; HP, $10.2 \mu \mathrm{mol} \mathrm{L}{ }^{-1}$. The error bars indicate the standard deviations $(n=3)$. Different letters (lower case for LC and capital for HC) above error bars represent significant differences $(P<0.05)$ among nutrient treatments while horizontal bars represent significant differences $(P<0.05)$ between LC and HC within a nutrient treatment.

To understand the photosynthetic performance of $U$. linza under various $p \mathrm{CO}_{2}$ and nutrient conditions, relative electron transport rate in PSII at $300 \mu \mathrm{mol}$ photons $\mathrm{m}^{-2} \mathrm{~s}^{-1}$ was measured (Fig. 4). It was found that $p \mathrm{CO}_{2}$ had an interactive effect with nutrients and each factor had a main effect (Table 4). Specifically, HC reduced rETR under LP but did not change it under HP. Regardless of $p \mathrm{CO}_{2}$ levels, $\mathrm{N}$ limitation reduced $\mathrm{rETR}(P=0.028)$, $\mathrm{P}$ limitation had a larger negative effect $(P<0.001)$, and the combination of LN and LP resulted in the lowest rETR values $(P<0.001)$.

Changes in photosynthetic pigments are shown in Fig. 5. Both $p \mathrm{CO}_{2}$ and nutrients had an effect on the content of $\mathrm{Chl}$ $a$ and $\mathrm{Chl} b$ (Table 4) but slight differences between Chl $a$ and $\mathrm{Chl} b$ were found after post hoc Tukey HSD $(P=0.05)$

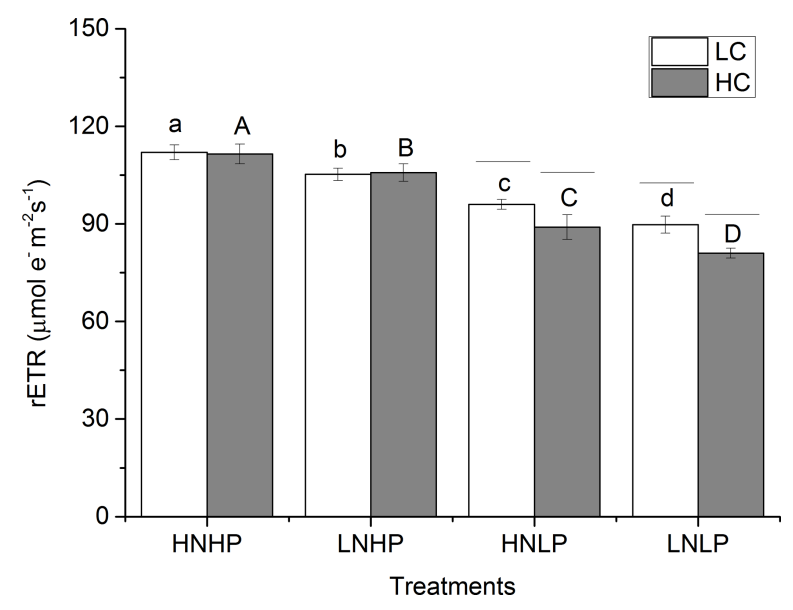

Figure 4. Relative electron transport rate (rETR) of adult $U$. linza grown under various conditions. LC, $400 \mu \mathrm{atm}$; HC, $1000 \mu \mathrm{atm}$; LN, $6.1 \mu \mathrm{mol} \mathrm{L}^{-1}$; LP, $0.2 \mu \mathrm{mol} \mathrm{L}^{-1}$; HN, $106.1 \mu \mathrm{mol} \mathrm{L}-1$; HP, $10.2 \mu \mathrm{mol} \mathrm{L}{ }^{-1}$. The error bars indicate the standard deviations $(n=$ 3 ). Different letters above the error bars (lower case for LC and capital for HC) represent significant differences $(P<0.05)$ among nutrient treatments while horizontal bars represent significant differences $(P<0.05)$ between LC and HC within a nutrient treatment.

tests had been conducted. Under LC, either $\mathrm{N}$ or P limitation reduced $\mathrm{Chl} a$ content, with $\mathrm{P}$ limitation having a larger effect. LNLP decreased Chl $a$ content further. Under HC, LN or LP reduced Chl $a$ but the combination of limiting nutrients did not lead to a further decrease. As far as Chl $b$ is concerned, either LN or LP decreased Chl $b$, with LP having a larger effect under LC. The combination of LN and LP did not lead to a further decrease compared with LP.

To investigate the effects of $p \mathrm{CO}_{2}$ and nutrients on nitrogen acquisition, RNA in adult $U$. linza grown under various conditions was measured (Fig. 6). Both $p \mathrm{CO}_{2}$ and nutrients affected NRA and they had an interactive effect (Table 4). Under LC, post hoc Tukey HSD comparison $(P=0.05)$ showed that either $\mathrm{N}$ or P limitation reduced NRA but the combination of them did not result in a further decrease. Under HC, N limitation and P limitation reduced NRA by 
Table 4. Two-way analysis of variance for the effects of $p \mathrm{CO}_{2}$ and nutrients on physiological parameters of $U$. linza; $p \mathrm{CO}_{2}{ }^{*}$ nutrients means the interactive effect of $p \mathrm{CO}_{2}$ and nutrients, df means degree of freedom, $F$ means the value of $F$ statistic, and Sig. means $p$ value.

\begin{tabular}{|c|c|c|c|c|c|c|c|c|c|c|c|c|}
\hline \multirow[t]{2}{*}{ Source } & \multicolumn{3}{|c|}{$p \mathrm{CO}_{2}$} & \multicolumn{3}{|c|}{ Nutrient } & \multicolumn{3}{|c|}{$p \mathrm{CO}_{2} *$ nutrient } & \multicolumn{3}{|c|}{ Error } \\
\hline & df & $F$ & Sig. & df & $F$ & Sig. & df & $F$ & Sig. & df & $F$ & Sig. \\
\hline Growth of sporeling & 1 & 115.297 & $<0.001$ & 3 & 12678.566 & $<0.001$ & 3 & 22.905 & $<0.001$ & 16 & & \\
\hline Growth of adult & 1 & 20.039 & $<0.001$ & 3 & 307.073 & $<0.001$ & 3 & 1.723 & 0.011 & 16 & & \\
\hline Net photosynthetic rate & 1 & 35.096 & $<0.001$ & 3 & 493.992 & $<0.001$ & 3 & 2.619 & 0.087 & 16 & & \\
\hline Dark respiration rate & 1 & 2.306 & 0.148 & 3 & 1.445 & 0.267 & 3 & 0.410 & 0.748 & 16 & & \\
\hline rETR & 1 & 14.592 & 0.002 & 3 & 135.690 & $<0.001$ & 3 & 5.023 & 0.012 & 16 & & \\
\hline Chl $a$ & 1 & 85.900 & $<0.001$ & 3 & 217.334 & $<0.001$ & 3 & 2.440 & 0.102 & 16 & & \\
\hline Chl $b$ & 1 & 71.600 & $<0.001$ & 3 & 104.483 & $<0.001$ & 3 & 2.005 & 0.154 & 16 & & \\
\hline Nitrate reductase activity & 1 & 38.271 & $<0.001$ & 3 & 100.487 & $<0.001$ & 3 & 6.246 & 0.005 & 16 & & \\
\hline Soluble protein & 1 & 30.212 & $<0.001$ & 3 & 106.523 & $<0.001$ & 3 & 11.295 & $<0.001$ & 16 & & \\
\hline
\end{tabular}

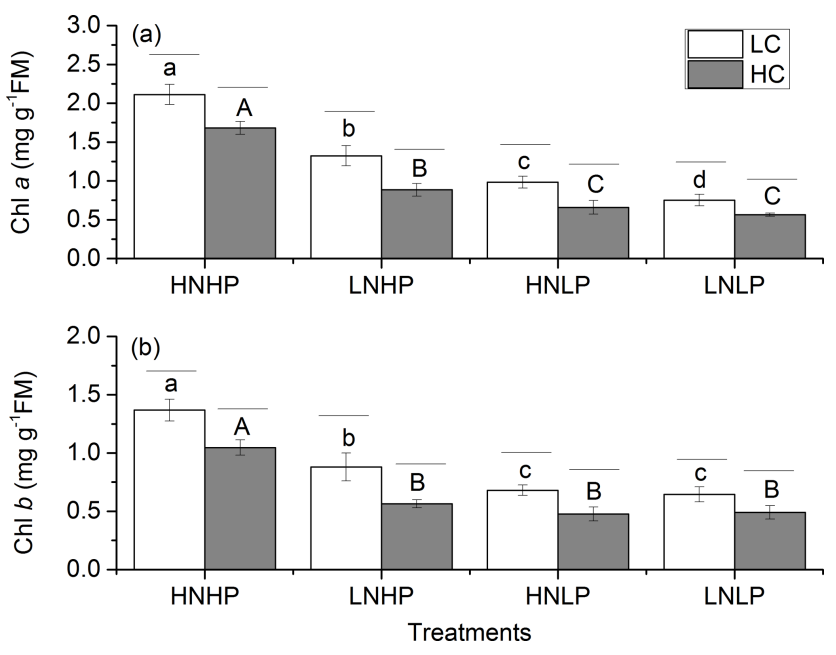

Figure 5. Content of $\mathrm{Chl} a$ (a) and $\mathrm{Chl} b$ (b) in adult $U$. linza grown under various conditions. LC, $400 \mu \mathrm{atm}$; HC, $1000 \mu \mathrm{atm}$; $\mathrm{LN}, 6.1 \mu \mathrm{mol} \mathrm{L}^{-1}$; LP, $0.2 \mu \mathrm{mol} \mathrm{L}^{-1}$; HN, $106.1 \mu \mathrm{mol} \mathrm{L}^{-1}$; HP, $10.2 \mu \mathrm{mol} \mathrm{L}^{-1}$. The error bars indicate the standard deviations $(n=$ 3). Different letters (lower case for LC and capital for HC) above the error bars represent significant differences $(P<0.05)$ among nutrient treatments while horizontal bars represent significant differences $(P<0.05)$ between LC and HC within a nutrient treatment.

22.8 and $37.7 \%$ respectively and the combination of them increased NRA by $45.6 \%$. In addition, HC did not affect NRA under LNLP $(P=0.700)$ but increased it when N $(P=$ $0.018)$ or $\mathrm{P}(P<0.001)$ was replete and nitrate reductase had the highest activity $\left(11.9 \pm 0.7 \mu \mathrm{molNO} \mathrm{NO}_{2}^{-} \mathrm{g}^{-1} \mathrm{FMh}^{-1}\right)$ under HCHNHP conditions $(P<0.001)$.

The content of soluble protein was assayed to investigate nitrogen assimilation of $U$. linza under various $p \mathrm{CO}_{2}$ and nutrient conditions (Fig. 7). Both $p \mathrm{CO}_{2}$ and nutrient levels affected the content of soluble protein and showed interactive effects (Table 4). Post hoc Tukey HSD comparison $(P=0.05)$ showed that HC did not affect the content of soluble protein under LP but increased it under HP. Under LC,

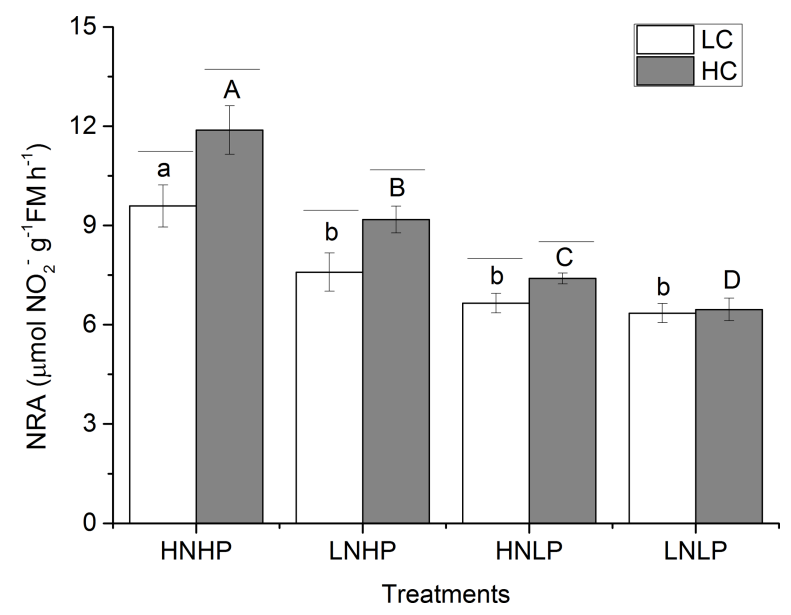

Figure 6. Nitrate reductase activity (NRA) in adult $U$. linza grown under various conditions. LC, $400 \mu \mathrm{atm}$; HC, $1000 \mu \mathrm{atm}$; $\mathrm{LN}, 6.1 \mu \mathrm{mol} \mathrm{L}^{-1}$; LP, $0.2 \mu \mathrm{mol} \mathrm{L}^{-1} ; \mathrm{HN}, 106.1 \mu \mathrm{mol} \mathrm{L}^{-1} ; \mathrm{HP}$, $10.2 \mu \mathrm{mol} \mathrm{L}{ }^{-1}$. The error bars indicate the standard deviations $(n=$ 3 ). Different letters (lower case for LC and capital for HC) above the error bars represent significant differences $(P<0.05)$ among nutrient treatments while horizontal bars represent significant differences $(P<0.05)$ between LC and HC within a nutrient treatment.

separate $\mathrm{N}$ or $\mathrm{P}$ limitation and their combination showed a similar negative effect on soluble protein content. Under HC, $\mathrm{P}$ limitation had a larger inhibition effect on soluble protein content compared to $\mathrm{N}$ limitation $(P<0.001)$ and the combination of $\mathrm{N}$ and $\mathrm{P}$ limitation did not lead to a further decrease in soluble protein content $(P=0.953)$.

\section{Discussions}

\subsection{Differential response of young and adult Ulva}

Compared to adult plants, young Ulva grew much faster regardless of culture conditions. This trend was also found in $U$. rigida (Gao et al., 2017a). The noticeable difference 




Figure 7. Content of soluble protein in adult $U$. linza grown under various conditions. LC, $400 \mu \mathrm{atm}$; HC, $1000 \mu \mathrm{atm}$; $\mathrm{LN}, 6.1 \mu \mathrm{mol} \mathrm{L}^{-1}$; LP, $0.2 \mu \mathrm{mol} \mathrm{L}^{-1}$; HN, $106.1 \mu \mathrm{mol} \mathrm{L}^{-1}$; HP, $10.2 \mu \mathrm{mol} \mathrm{L}^{-1}$. The error bars indicate the standard deviations $(n=$ 3). Different letters (lower case for LC and capital for HC) above the error bars represent significant differences $(P<0.05)$ among nutrient treatments while horizontal bars represent significant differences $(P<0.05)$ between LC and HC within a nutrient treatment.

in growth rate between young and adult Ulva could be attributed to cell differentiation. In the early life history of Ulva, cell division proceeds fast as all cells are of the same type, developing from one single cell. Thereafter, cells differentiate into two types: rhizoidal cells in the basal part and blade cells in the marginal part (Gao et al., 2017b). Differences in cell size and photosynthetic pigments between these two cell types result in unequal growth in the thallus; the growth of rhizoidal cells is much slower than in blade cells (Han et al., 2003; Lüning et al., 2008), which slows down the total growth of the thallus as it ages.

Lower P levels strongly inhibited the growth of both young and adult plants in this study and the inhibitory effect was particularly significant for young plants. Gao et al. (2017b) has reported that $U$. rigida becomes mature when the thalli reach a length of around $1.5 \mathrm{~cm}$ and we also found a similar phenomenon in $U$. linza. Young plants grown under P limitation were far away from the mature stage even after 16 days of culture while the plants grown under $P$ repletion reached a mature stage by day 11 and the length could be up to $16 \mathrm{~cm}$ by day 16. This finding supports the significant role of $\mathrm{P}$ in development of $U$. linza. Phosphorus (P) is an essential element for seaweeds, in the form of nucleic acids, phospholipids, ATP and ADP, but little is known regarding the effect of $\mathrm{P}$ on the development of seaweed. Our findings indicate that $\mathrm{P}$ limitation may terminate the development of young Ulva and cause it to remain in the immature stage. The separate addition of $\mathrm{N}$ did not change the growth rate of young plants but increased the growth rate of adult plants, suggesting that adult plants could be more resilient to $\mathrm{P}$ limitation compared to young plants.

\subsection{Photosynthetic response to $\mathrm{OA}$ and nutrients}

$\mathrm{HC}$ was shown in the present study to decrease the Chl $a$ and $\mathrm{Chl} b$ contents of $U$. linza. High $\mathrm{CO}_{2}$ commonly downregulates algal $\mathrm{CO}_{2}$ concentrating mechanisms (CCMs), suggesting less energy is required to drive CCMs (Gao et al., 2012; Raven et al., 2012, 2017; Cornwall et al., 2017). This may lead to decreased synthesis of pigment for energy capture. This phenomenon of "pigment economy" has also been found in the previous studies regarding Ulva species (Gordillo et al., 2003; Gao et al., 2016). Deficiency in $\mathrm{N}$ and/or $\mathrm{P}$ supply also reduced pigment content in this study. Nitrogen is a major component of Chl $a$. Although P is a nonconstituent element in $\mathrm{Chl} a$, higher $\mathrm{P}$ supply may stimulate the activity of Chl $a$ synthesis-related enzymes (Xu et al., 2017). Accordingly, in this study nutrient ( $N$ and $P$ ) enrichment enhanced the synthesis of $\mathrm{Chl} a$. This is consistent with other findings in Ulva species (Gordillo et al., 2001; Figueroa et al., 2009) and other macroalgae (Xu et al., 2017).

$\mathrm{HC}$ decreased net photosynthetic rate in $U$. linza in the present study. This could be due to the decrease in photosynthetic pigment in thalli grown under HC. Meanwhile, the saved energy due to down-regulation of CCMs in thalli grown under HC combined with higher light density used in this study may depress PSII activity and thus reduce net photosynthetic rate (Gao et al., 2012). An ocean acidificationinduced decrease in net photosynthetic rate was also documented in $U$. prolifera ( $\mathrm{Xu}$ and Gao, 2012). In terms of the effects of nutrients, $\mathrm{N}$ limitation reduced net photosynthetic rate in $U$. linza and $\mathrm{P}$ limitation resulted in a further decrease. The negative effects of $\mathrm{N}$ and $\mathrm{P}$ limitation on algal photosynthetic rate have been extensively reported (Longstaff et al., 2002; Kang and Chung, 2017; Xu et al., 2017), indicating the important role of $\mathrm{N}$ and $\mathrm{P}$ in algal photosynthesis. In addition to the separate effects of $p \mathrm{CO}_{2}$ or nutrients, these factors also interplay on photosynthetic performances of $U$. linza. For instance, HC reduced rETR under LP but did not affect it under $\mathrm{HP}$, suggesting that $\mathrm{P}$ enrichment could offset the negative effect of ocean acidification. In contrast to net photosynthetic rate, the dark respiration rate of thalli was insensitive to the change in $p \mathrm{CO}_{2}$ or nutrients. The higher $p \mathrm{CO}_{2}$ did not affect the dark respiration rate in $U$. prolifera either (Xu and Gao, 2012) but reduced it in U. rigida (Gordillo et al., 2003). $\mathrm{N}$ enrichment did not affect the dark respiration rate under lower $p \mathrm{CO}_{2}$ but reduced it under higher $p \mathrm{CO}_{2}$ for $U$. rigida (Gordillo et al., 2003). The present finding combined with the previous studies indicates that response of dark respiration in Ulva may be species-dependent.

\section{3 $\mathrm{N}$ assimilation under $\mathrm{OA}$ and nutrient limitation}

Contrary to $\mathrm{C}$ assimilation, $\mathrm{HC}$ did not affect the content of soluble protein under LP and even increased it when the $\mathrm{P}$ level was sufficient. The increased protein synthesis under $\mathrm{HC}$ could be put down to the stimulation of NRA under HC. 
Gordillo et al. (2001) proposed that the positive effect of HC on $\mathrm{N}$ assimilation may be due to a direct action on synthesis of NR rather than the physiological consequences of $\mathrm{C}$ metabolism as occurs in higher plants. Our results support this hypothesis because HC increased NRA in thalli grown under HP in this study. Meanwhile, the change in NRA under different $p \mathrm{CO}_{2}$ levels might be also caused by varying $\mathrm{pH}$ as $\mathrm{pH}$ could affect NRA in seaweeds (Lopes et al., 1997). $\mathrm{P}$ is considered to be playing a critical role in enzyme synthesis and may interact with $\mathrm{CO}_{2}$ to promote the synthesis and activity of nitrate reductase.

\subsection{Interactive effects of $\mathrm{OA}$ and nutrient limitation on growth}

$\mathrm{HC}$ did not affect the growth of thalli when $\mathrm{P}$ was replete in the medium. Since HC reduced photosynthesis rate but increased NRA and protein synthesis, the lack of effect of $\mathrm{HC}$ may be an integrated outcome of $\mathrm{C}$ and $\mathrm{N}$ assimilation (Fig. 8). This finding is different from our previous studies in which HC increased the growth rate of $U$. linza (Gao et al., 2016) and U. prolifera (Gao et al., 2017d). The possible reason for this divergence might be the different light intensities that were used in the various studies. For the previous studies, a lower light intensity of $100 \mu \mathrm{mol}$ photons $\mathrm{m}^{-2} \mathrm{~s}^{-1}$ was used for algal culture while a higher light intensity of $300 \mu \mathrm{mol}$ photons $\mathrm{m}^{-2} \mathrm{~s}^{-1}$ was used in the present work. Ocean acidification could interact with light intensity to affect algal growth. It has commonly been reported that ocean acidification can increase algal photosynthesis and growth at lower light intensity and inhibit them at higher light intensity (Gao et al., 2012, 2016; Xu and Gao, 2012), with inversion points of PAR around 160, 125 and $178 \mu \mathrm{mol}$ photons $\mathrm{m}^{-2} \mathrm{~s}^{-1}$ for Phaeodactylum tricornutum, Thalassiosira pseudonana and Skeletonema costatum respectively (Gao et al., 2012). The potential reason is that the saved energy from down-regulated CCMs under higher $\mathrm{CO}_{2}$ levels could be used for growth at lower light levels but could inhibit PSII activity and thus growth at higher light levels (Gao et al., 2012, 2016). It seems that $U$. linza has a higher inversion point compared to diatoms.

Furthermore, $\mathrm{HC}$ reduced the growth of $U$. linza when $\mathrm{P}$ was limited. In addition to the increased $\mathrm{CO}_{2}$ supply, ocean acidification also reduces the $\mathrm{pH}$ of seawater, which has been deemed a stressor disturbing the acid-base balance both at the cell surface and within cells and affecting algal photosynthetic performance (Flynn et al., 2012; Gao et al., 2017d). Increased $\mathrm{CO}_{2}$ and decreased $\mathrm{pH}$ also reduced rETR and net photosynthetic rate of $U$. linza in the present study. Xu et al. (2017) proposed that algae could synthesize HC transportrelated proteins to combat that disturbance. Under P limitation conditions, such protein synthesis could be limited, which may lead to the decreased rETR and net photosynthetic rate and thus to the decreased growth observed in the present study. Until now, most studies of ocean acidification

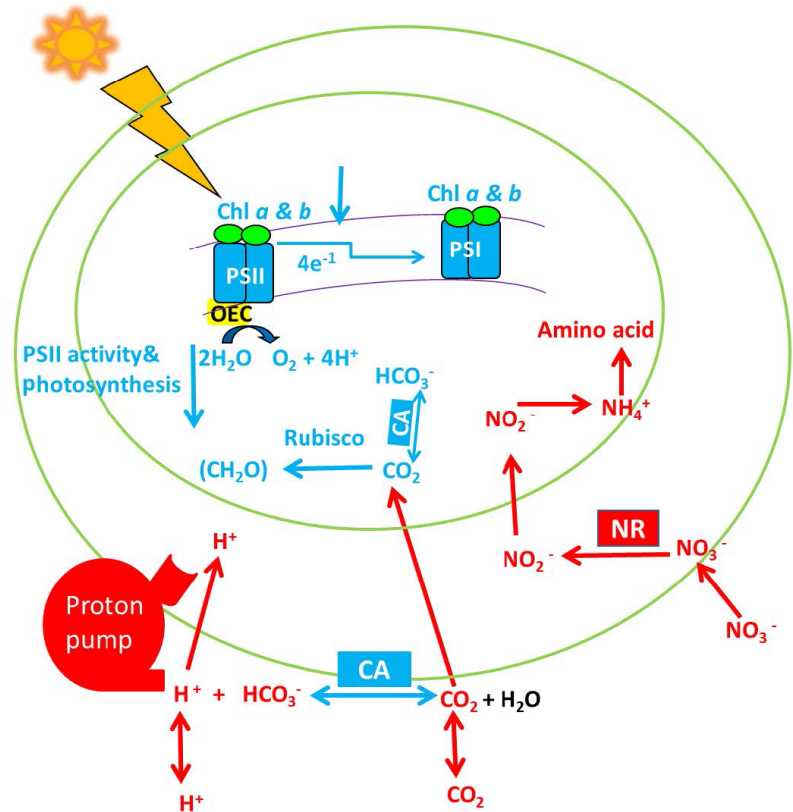

Figure 8. Physiological responses of $U$. linza to the combination of ocean acidification and nutrient availability. The blue and the red symbols represent down- and up-regulated metabolic pathways respectively. PSI: Photosystem I; PSII: Photosystem II; OEC: oxygenevolving complex; NPQ: non-photochemical quenching; CA: carbonic anhydrase; NR: nitrate reductase.

on seaweed have been conducted under nutrient-replete conditions. The present study thus demonstrates the contrasting effect of ocean acidification under nutrient-poor conditions.

\subsection{Differential effects of $\mathrm{N}$ and $\mathrm{P}$ limitation}

In the present study, compared to $\mathrm{N}$ limitation, $\mathrm{P}$ limitation seems to have a larger negative effect on physiological performances in $U$. linza. In other words, the addition of $\mathrm{P}$ resulted in a larger stimulating effect compared to $\mathrm{N}$ addition. The question of which one (N or $\mathrm{P})$ is the nutrient most likely to limit marine primary productivity has been a controversial issue until now (Elser et al., 2007; Teichberg et al., 2010; Müller and Mitrovic, 2015). It has been proposed that the occurrence of $\mathrm{N}$ or $\mathrm{P}$ limitation depends on the difference in $\mathrm{N}: \mathrm{P}$ ratio between in algal tissue and in seawater; when the ratio of $\mathrm{N}: \mathrm{P}$ in algal tissue is higher than in seawater, $\mathrm{N}$ limitation is indicated, and the opposite is considered as $\mathrm{P}$ limitation (Harrison and Hurd, 2001). The ratio of $\mathrm{N}: \mathrm{P}$ in tissue of $U$. linza grown in the field has not been documented and the mean value of $\mathrm{N}$ : $\mathrm{P}$ throughout a year is 15.4 for $U$. prolifera and 22.3 for $U$. fenestrate (Wheeler and Björnsäter, 1992). The ratio of $\mathrm{N}: \mathrm{P}$ in natural seawater where the samples were collected in the present study is $30.7: 1$, which is higher than the $\mathrm{N}: \mathrm{P}$ ratio in the reported Ulva species. This suggests the existence of $\mathrm{P}$ limitation for $U$. linza, which could explain the larger stimulating effect with $\mathrm{P}$ addition. 
In recent decades, $\mathrm{P}$ limitation has been suggested to commonly occur in coastal waters due to more effective $P$ removal from industrial and domestic wastewater during de-eutrophication processes (Grizzetti et al., 2012). For instance, the ratio of dissolved inorganic $\mathrm{N}: \mathrm{P}$ could be as high as $375: 1$ in nearshore waters of the North Sea, resulting in severe P limitation for algal growth (Burson et al., 2016).

\section{Conclusions}

With the continuous emission of $\mathrm{CO}_{2}$, the trend of ocean acidification will continue through this century (Gattuso et al., 2015). Meanwhile, nutrient limitation would occur in coastal waters as a consequence of efforts on deeutrophication. Measures to reduce eutrophication have often led to a more effective decline of phosphorus than nitrogen concentrations (Burson et al., 2016). In addition, intensive seaweed culture in coastal areas can also lead to noticeable decreases in N and P (He et al., 2008; Wu et al., 2015). Our study demonstrates that ocean acidification and nutrient limitation would synergistically inhibit development and growth of Ulva species. This may hinder the occurrence of green tides and Ulva cultivation in oceans in the future. In addition, it has been reported that fast-growing species require high nutrient inputs to sustain growth, while slow-growing species are better adapted to nutrient-limiting conditions (Gordillo, 2012). The decrease in nutrient level may result in a shift in seaweed community composition in the future ocean environment. Studies on other seaweeds are needed to have a comprehensive understanding in terms of the combined effects of global and local stressors on seaweed communities.

Data availability. The underlying research data can be found in the Supplement.

\section{The Supplement related to this article is available online} at https://doi.org/10.5194/bg-15-3409-2018-supplement.

Competing interests. The authors declare that they have no conflict of interest.

Acknowledgements. This study was supported by the National Natural Science Foundation of China (no. 41476097), the Natural Science Foundation of Jiangsu Province (no. BK20161295), the Science and Technology Bureau of Lianyungang (SH1606), the China Postdoctoral Science Foundation (2017M620270), the Jiangsu Planned Projects for Postdoctoral Research Funds (1701003A), the Science Foundation of Huaihai Institute of Technology (Z2016007), and the Priority Academic Program Development of Jiangsu Higher Education Institutions of China.
Edited by: S. Wajih A. Naqvi

Reviewed by: four anonymous referees

\section{References}

Baydend, R., Joannei, T., Lauraj, F., and Seand, C.: Synergistic effects of climate change and local stressors: $\mathrm{CO}_{2}$ and nutrientdriven change in subtidal rocky habitats, Glob. Change Biol., 15, 2153-2162, 2010.

Boelen, P., Van De Poll, W. H., Van Der Strate, H. J., Neven, I. A., Beardall, J., and Buma, A. G.: Neither elevated nor reduced $\mathrm{CO}_{2}$ affects the photophysiological performance of the marine Antarctic diatom Chaetoceros brevis, J. Exp. Mar. Biol. Ecol., 406, 38-45, 2011.

Bradford, M. M.: A rapid and sensitive method for the quantitation of microgram quantities of protein utilizing the principle of protein-dye binding, Anal. Biochem., 72, 248-254, 1976.

Burson, A., Stomp, M., Akil, L., Brussaard, C. P., and Huisman, J.: Unbalanced reduction of nutrient loads has created an offshore gradient from phosphorus to nitrogen limitation in the North Sea, Limnol. Oceanogr., 61, 869-888, 2016.

Cornwall, C. E., Revill, A. T., Hall-Spencer, J. M., Milazzo, M., Raven, J. A., and Hurd, C. L.: Inorganic carbon physiology underpins macroalgal responses to elevated $\mathrm{CO}_{2}$, Scientific Reports, 7, 46297, https://doi.org/10.1038/srep46297, 2017.

Corzo, A. and Niell, F. X.: Determination of nitrate reductase activity in Ulva rigida C. Agardh by the in situ method, J. Exp. Mar. Biol. Ecol., 146, 181-191, 1991.

Deng, M. D., Moureaux, T., Cherel, I., Boutin, J. P., and Caboche, M.: Effects of nitrogen metabolites on the regulation and circadian expression of tobacco nitrate reductase, Plant Physiol. Bioch., 29, 239-247, 1991.

Eberlein, T., Wohlrab, S., Rost, B., John, U., Bach, L. T., Riebesell, U., and Van de Waal, D. B.: Effects of ocean acidification on primary production in a coastal North Sea phytoplankton community, PloS One, 12, e0172594, https://doi.org/10.1371/journal.pone.0172594, 2017.

Eggert, A.: Seaweed responses to temperature, in: Seaweed biology, edited by: Wiencke, C. and Bischof, K., 47-66, Springer, Berlin, 2012.

Elser, J. J., Bracken, M. E., Cleland, E. E., Gruner, D. S., Harpole, W. S., Hillebrand, H., Ngai, J. T., Seabloom, E. W., Shurin, J. B., and Smith, J. E.: Global analysis of nitrogen and phosphorus limitation of primary producers in freshwater, marine and terrestrial ecosystems, Ecol. Lett., 10, 1135-1142, 2007.

Figueroa, F. L., Israel, A., Neori, A., Martínez, B., Malta, E. J., Ang Jr., P., Inken, S., Marquardt, R., and Korbee, N.: Effects of nutrient supply on photosynthesis and pigmentation in Ulva lactuca (Chlorophyta): responses to short-term stress, Aquat. Biol., 7, 173-183, 2009.

Flynn, K. J., Blackford, J. C., Baird, M. E., Raven, J. A., Clark, D. R., Beardall, J., Brownlee, C., Fabian, H., and Wheeler, G. L.: Changes in $\mathrm{pH}$ at the exterior surface of plankton with ocean acidification, Nature Clim. Change, 2, 510-513, 2012.

Gao, G., Clare, A. S., Rose, C., and Caldwell, G. S.: Eutrophication and warming-driven green tides (Ulva rigida) are predicted to increase under future climate change scenarios, Mar. Pollut. Bull., 114, 439-447, 2017a. 
Gao, G., Clare, A. S., Rose, C., and Caldwell, G. S.: Intrinsic and extrinsic control of reproduction in the green tide-forming alga, Ulva rigida, Environ. Exp. Bot., 139, 14-22, 2017b.

Gao, G., Jin, P., Liu, N., Li, F., Tong, S., Hutchins, D. A., and Gao, K.: The acclimation process of phytoplankton biomass, carbon fixation and respiration to the combined effects of elevated temperature and $p \mathrm{CO}_{2}$ in the northern South China Sea, Mar. Pollut. Bull., 118, 213-220, 2017c.

Gao, G., Liu, Y., Li, X., Feng, Z., and Xu, J.: An ocean acidification acclimatised green tide alga is robust to changes of seawater carbon chemistry but vulnerable to light stress, PLoS One, 11, e0169040, https://doi.org/10.1371/journal.pone.0169040, 2016.

Gao, G., Liu, Y., Li, X., Feng, Z., Xu, Z., Wu, H., and Xu, J.: Expected $\mathrm{CO}_{2}$-induced ocean acidification modulates copper toxicity in the green tide alga Ulva prolifera, Environ. Exp. Bot., 135, 63-72, 2017d.

Gao, G., Shi, Q., Xu, Z., Xu, J., Campbell, D. A., and Wu, H.: Global warming interacts with ocean acidification to alter PSII function and protection in the diatom Thalassiosira weissflogii, Environ. Exp. Bot., 147, 95-103, 2018.

Gao, K., Xu, J., Gao, G., Li, Y., Hutchins, D. A., Huang, B., Wang, W., Zheng, Y., Jin, P., Cai, X., Hader, D. P., Li, W., Xu, K., Liu, N., and Riebesell, U.: Rising $\mathrm{CO}_{2}$ and increased light exposure synergistically reduce marine primary productivity, Nature Clim. Change, 2, 519-523, 2012.

Gattuso, J. P., Magnan, A., Billé, R., Cheung, W. W., Howes, E. L., Joos, F, Allemand, D., Bopp, L., Cooley, S. R., Eakin, C. M., Hoegh-Guldberg, O., Kelly, R. P., Pörtner, H.-O, Rogers, A. D., Baxter, J. M., Laffoley, D., Osborn, D., Rankovic, A., Rochette, J., Sumaila, U. R., Treyer, S., and Turley, C.: Contrasting futures for ocean and society from different anthropogenic $\mathrm{CO}_{2}$ emissions scenarios, Science, 349, 45-55, 2015.

Gordillo, F. J. L.: Environment and Algal Nutrition, in: Seaweed biology: novel insights into ecophysiology, ecology and utilization, edited by: Wiencke, C. and Bischof, K., Springer, Berlin, 2012.

Gordillo, F. J., Niell, F. X., and Figueroa, F. L.: Non-photosynthetic enhancement of growth by high $\mathrm{CO}_{2}$ level in the nitrophilic seaweed Ulva rigida C. Agardh (Chlorophyta), Planta, 213, 64-70, 2001.

Gordillo, F. J. L., Figueroa, F. L., and Niell, F. X.: Photon-and carbon-use efficiency in Ulva rigida at different $\mathrm{CO}_{2}$ and $\mathrm{N}$ levels, Planta, 218, 315-322, 2003.

Grizzetti, B., Bouraoui, F., and Aloe, A.: Changes of nitrogen and phosphorus loads to European seas, Glob. Change Biol., 18, 769782, 2012.

Han, T., Han, Y. S., Kain, J. M., and Häder, D. P.: Thallus differentiation of photosynthesis, growth, reproduction, and UV-B sensitivity in the green alga Ulva pertusa (Chlorophyceae), J. Phycol., 39, 712-721, 2003.

Harrison, P. J. and Hurd, C. L.: Nutrient physiology of seaweeds: Application of concepts to aquaculture, Cah. Biol. Mar., 42, 71$82,2001$.

He, P., Xu, S., Zhang, H., Wen, S., Dai, Y., Lin, S., and Yarish, C.: Bioremediation efficiency in the removal of dissolved inorganic nutrients by the red seaweed, Porphyra yezoensis, cultivated in the open sea, Water Res., 42, 1281-1289, 2008.

Howarth, R., Anderson, D., Cloern, J., Elfring, C., Hopkins, C., Lapointe, B., Malone, T., Marcus, N., McGlathery, K., Sharply, A., and Walker, D.: Nutrient pollution of coastal rivers, bays, and seas, Issues in Ecology, 7, 1-14, 2000.

Kang, J. W. and Chung, I. K.: The effects of eutrophication and acidification on the ecophysiology of Ulva pertusa Kjellman, J. Appl. Phycol., 29, 2675-2683, 2017.

Lapointe, B. E.: Nutrient thresholds for bottom-up control of macroalgal blooms on coral reefs in Jamaica and southeast Florida, Limnol. Oceanogr., 42, 1119-1131, 1997.

Lapointe, B. E. and Bedford, B. J.: Ecology and nutrition of invasive Caulerpa brachypus f. parvifolia blooms on coral reefs off southeast Florida, U.S.A., Harmful Algae, 9, 1-12, 2010.

Li, W., Gao, K., and Beardall, J.: Nitrate limitation and ocean acidification interact with UV-B to reduce photosynthetic performance in the diatom Phaeodactylum tricornutum, Biogeosciences, 12, 2383-2393, https://doi.org/10.5194/bg-12-23832015, 2015.

Longstaff, B. J., Kildea, T., Runcie, J. W., Cheshire, A., Dennison, W. C., Hurd, C., Kana, T., Raven, J. A., and Larkum, A. W.: An in situ study of photosynthetic oxygen exchange and electron transport rate in the marine macroalga Ulva lactuca (Chlorophyta), Photosynth. Res., 74, 281-293, 2002.

Lopes, P. F., Oliveira, M. C., and Colepicolo, P.: Diurnal fluctuation of nitrate reductase activity in the marine red alga Gracilaria tenuistipitata (Rhodophyta), J. Phycol., 33, 225-231, 1997.

Lüning, K., Kadel, P., and Pang, S.: Control of reproduction rhythmicity by environmental and endogenous signals in Ulva pseudocurvata (Chlorophyta), J. Phycol., 44, 866-873, 2008.

Luo, M. B., Liu, F., and Xu, Z. L.: Growth and nutrient uptake capacity of two co-occurring species, Ulva prolifera and Ulva linza, Aquat. Bot., 100, 18-24, 2012.

McCarthy, A., Rogers, S. P., Duffy, S. J., and Campbell, D. A.: Elevated carbon dioxide differentially alters the photophysiology of Thalassiosira pseudonana (Bacillariophyceae) and Emiliania huxleyi (Haptophyta), J. Phycol., 48, 635-646, 2012.

Mostofa, K. M. G., Liu, C.-Q., Zhai, W., Minella, M., Vione, D., Gao, K., Minakata, D., Arakaki, T., Yoshioka, T., Hayakawa, K., Konohira, E., Tanoue, E., Akhand, A., Chanda, A., Wang, B., and Sakugawa, H.: Reviews and Syntheses: Ocean acidification and its potential impacts on marine ecosystems, Biogeosciences, 13 1767-1786, https://doi.org/10.5194/bg-13-1767-2016, 2016.

Msuya, F. E. and Neori, A.: Effect of water aeration and nutrient load level on biomass yield, $\mathrm{N}$ uptake and protein content of the seaweed Ulva lactuca cultured in seawater tanks, J. Appl. Phycol., 20, 1021-1031, 2008.

Müller, S. and Mitrovic, S. M.: Phytoplankton co-limitation by nitrogen and phosphorus in a shallow reservoir: progressing from the phosphorus limitation paradigm, Hydrobiologia, 744, 255269, 2015.

Nixon, S. W. and Pilson, M. E. Q.: Nitrogen in estuarine and coastal marine ecosystems, in: Nitrogen in the marine environment, edited by: Carpenter, E. J. and Capone, D. G., Academic Press, Berlin, 1983.

NOAA: available at: https://www.co2.earth/ (last access: 1 January 2018), 2017.

Rautenberger, R., Fernandez, P. A., Strittmatter, M., Heesch, S., Cornwall, C. E., Hurd, C. L., and Roleda, M. Y.: Saturating light and not increased carbon dioxide under ocean acidification drives photosynthesis and growth in Ulva rigida (Chlorophyta), Ecol. Evol., 5, 874-888, 2015. 
Raven, J. A., Giordano, M., Beardall, J., and Maberly, S. C.: Algal evolution in relation to atmospheric $\mathrm{CO}_{2}$ : carboxylases, carbonconcentrating mechanisms and carbon oxidation cycles, Philos. T. R. Soc. B, 367, 493-507, 2012.

Raven, J. A., Beardall, J., and Sánchez-Baracaldo, P.: The possible evolution, and future, of $\mathrm{CO}_{2}$-concentrating mechanisms, J. Exp. Bot., 68, 3701-3716, 2017.

Smetacek, V. and Zingone, A.: Green and golden seaweed tides on the rise, Nature, 504, 84-88, 2013.

Teichberg, M., Fox, M. T., Olsen, Y. O., Valiela, I., Martinetto, P., Iribarne, O., Muto, E. Y., Petti, M. A. V., Corbisier, T. N., Soto-Jiménez, M., Páez-Osuna, F., Castro, P., Freitas, H., Zitelli, A., Cardinaletti, M., and Tagliapietra, D.: Eutrophication and macroalgal blooms in temperate and tropical coastal waters: nutrient enrichment experiments with Ulva spp, Glob. Change Biol., 16, 2624-2637, 2010.

Velasco, P. J., Tischner, R., Huffaker, R. C., and Whitaker, J. R.: Synthesis and degradation of nitrate reductase during the cell cycle of Chlorella sorokiniana, Plant Physiol., 89, 220-224, 1989.

Villares, R., Puente, X., and Carballeira, A.: Nitrogen and phosphorus in Ulva sp. in the Galician Rias Bajas (northwest Spain): Seasonal fluctuations and influence on growth, Boletin - Instituto Espanol de Oceanografia, 15, 1-4, 1999.
Wang, H. M. D., Li, X. C., Lee, D. J., and Chang, J. S.: Potential biomedical applications of marine algae, Bioresour. Technol., 244, 1407-1415, 2017.

Wheeler, P. A. and Björnsäter, B. R.: Seasonal fluctuations in tissue nitrogen, phosphorus, and $\mathrm{n}: \mathrm{p}$ for five macroalgal species common to the pacific northwest coast, J. Phycol., 28, 1-6, 1992.

Wiencke, C. and Bischof, K.: Seaweed biology: novel insights into ecophysiology, ecology and utilization, Springer, Berlin, 2012.

Wu, H., Huo, Y., Zhang, J., Liu, Y., Zhao, Y., and He, P.: Bioremediation efficiency of the largest scale artificial Porphyra yezoensis cultivation in the open sea in China, Mar. Pollut. Bull., 95, 289296, 2015.

$\mathrm{Xu}$, J. and Gao, K.: Future $\mathrm{CO}_{2}$-induced ocean acidification mediates the physiological performance of a green tide alga, Plant Physiol., 160, 1762-1769, 2012.

$\mathrm{Xu}, \mathrm{Z}$., Gao, G., Xu, J., and Wu, H.: Physiological response of a golden tide alga (Sargassum muticum) to the interaction of ocean acidification and phosphorus enrichment, Biogeosciences, 14, 671-681, https://doi.org/10.5194/bg-14-671-2017, 2017.

Yuan, W., Gao, G., Shi, Q., Xu, Z., and Wu, H.: Combined effects of ocean acidification and warming on physiological response of the diatom Thalassiosira pseudonana to light challenges, Mar. Environ. Res., 135, 63-69, 2018 